Pre-copyedited version! Final version published in Central Asian Survey 29(3): 289-304.

\title{
Rulers and Rascals: The Politics of Gold in Qing Mongolian History
}

\author{
High, M.M. ${ }^{a 1}$ and Schlesinger, J. ${ }^{\text {b }}$ \\ ${ }^{a}$ Department of Anthropology, London School of Economics, London, UK. \\ ${ }^{b}$ History and East Asian Languages, Harvard University, Cambridge, USA.
}

\begin{abstract}
This article examines the politics of gold mining in the Mongolian cultural region during the Qing period and today. By drawing on archival material and accounts by travellers of the period, we situate the current mining boom within its greater historical context. Since the exploration of gold has been surrounded by enduring notions of exclusivity and purity, the article shows how the mining for gold has historically been closely related to Mongolian practices of political rulership. By examining the current mining boom in Mongolia from a broader historical perspective, the article argues that this extractive economy involves much more than a search for profit.
\end{abstract}

Keywords: gold mining; political rulership; wealth; Qing Empire; Mongolia.

Over the last decade Mongolia has become an attractive epicentre for prospectors and miners who seek plentiful and profitable mineral wealth. Fuelled by a free-market economy, large mineral discoveries and the fast growing realization that Mongolia can become a prime supplier of raw materials to China's thriving economy, a mining boom has materialized and brought luring promises of prosperity to investors and the Mongolian nation. Whilst Robert Friedland, the chairman of one of the world's largest copper and gold mines, Oyu Tolgoi, entices investors with his proclamation that mining in Mongolia is like making “T-shirts for five bucks and selling them for \$100” (Wall Street Journal 2007), the country awaits a forecasted 38 percent increase in the annual GDP derived from mining developments alone (World Growth Mongolia 2009:3). With more than 30 percent of the country licensed for mining purposes, mining is today the largest and fastest growing economic sector in Mongolia. Alongside formal sector mining, a large-scale informal gold rush has also emerged (High 2008). Attracting men and women, young and old, the gold rush involves more than 100,000 people and has spread throughout the country (ILO 2004:1). Whether formal or informal sector mining, the exploration of Mongolia's mineral wealth is growing and economic predictions continue to sustain a strong sense of anticipation.

Whilst the mining boom engenders future-oriented hopes and fears, it also serves as a reminder of the not-so-distant past. Only 20 years ago Mongolia was administered by a Soviet-socialist regime, had a centrally planned economy and a mining sector of minimal proportion ${ }^{2}$. To some, the growing mining 
Pre-copyedited version! Final version published in Central Asian Survey 29(3): 289-304.

sector of today evidences Mongolia's move away from a gloomy, stagnant and introverted past. To others, it highlights the problematic negotiation of interests in a society that no longer prioritizes social equality and security. In a country where nomadic pastoralism has historically been the largest economic sector (Humphrey and Sneath 1999), the current mining boom invites retrospective contemplation. Highlighting the connections and fractures between visions for the future and memories of the past, the growing mining industry has become a key marker of societal transformation. More than any other economic activity, today's mining has become emblematic of a 'changing Mongolia', a 'new Mongolia'.

This transformation is felt and expressed particularly in people's relation to the land. As an industry of extraction, the mining boom has not only generated profit from the land, but also destabilized its broader position within local cosmology. In Mongolia the land is not merely a national territory, a physical backdrop for human activity, or an enabling ecology. It is also a dynamic constituent in what makes people human. Recognizing the physical environment (baigal) as having life, feelings and agency, elaborate taboos inform people's engagement with the land. However, if such taboos are not adhered to, "if one part of nature denies the existence of another then eventually it will be denying its own" (Tseren 1996:147). As thousands of gold miners and mining companies currently uncover the land for its riches, the project of prosperity is seen to entail high stakes and is surrounded by much uncertainty.

Anxieties about the future, challenges to people's relationship with the land, and the experience of profound transformation are not unique to the present. Based on archival material of the Qing Empire (1644-1911), unique for its volume and variety of written records, and accounts by travellers of the period, we examine the historical politics of gold mining in the Mongolian cultural region ${ }^{3}$. Since the issues associated with mining today arose for the first time during the Qing period, this historical moment is particularly apt for examining Mongolian ideas about gold mining and societal transformations more generally. Both then and today, the hype of foreign prospectors, controversial mining concessions and the establishment of illegal mining camps have contributed to unsettling feelings about mining as cataclysmic for Mongolian ways of life. Alongside the production of substantial profit, gold mining has given rise to concerns about the exclusivity and purity of the land. Central to 'gold diplomacy' and trans-regional political relations, the mining of gold encapsulates the dynamic between Mongolian practices of rulership and local fears of incoming miners' intrusive behaviour. By drawing on the history of Qing Mongolia and situating current events within their greater historical context, we suggest a move away from presentist analyses that simplify and essentialise notions of 'transition' and 'modernity' - discourses that are also strong among the Mongolian public. Rather than merely confirming popular sentiments, this article demonstrates the importance of incorporating historical material that can problematise the present whilst also enhancing our understanding of the past. Whereas historians have to date largely approached the environmental history of Mongolia in terms of a long-standing heritage of environmental protection (Boldbaatar 2002, Gagengaowa and Wuyunbatu 2003, Wu Feng and Bao Qingde 2009), this article questions the monolithic construction of a national environmentalism. Recognizing the hopes and fears that have 
Pre-copyedited version! Final version published in Central Asian Survey 29(3): 289-304.

surrounded the extractive industry, we show how gold mining is not only a pressing issue today but has been a highly contentious issue in the politics of society and identity in Mongolia for centuries.

\section{The lure of gold}

The gold deposits in the Mongolian region have more than once given rise to speculation and investment. Gold fever first gripped the world's imagination in 1848 with the discovery of numerous large deposits in California. Gold rushes then ensued in Australia from 1853, British Columbia from 1858, Siberia from the 1860s, South Africa from 1886, and Canada from 1896. As these classic gold rushes spread across the world, the largely unchartered territory of Inner Asia presented international investors, entrepreneurs and adventurers with new and exciting prospects for further gold discoveries. The harsh weather and the arid land offered a promise of prosperity for those who dared to make the journey (Preobrazhensky 1993a, 1993b).

The age of prospecting also saw an unprecedented number of explorers, missionaries and diplomats venturing through the region. Fascinated by the quotidian as well as the extraordinary, these travellers amassed a wealth of novel material for their writings. Given the period of their travels, it is perhaps little wonder that they paid particular attention to the role of gold in local life. However, the fantastic stories coming from the Inner Asian lands, often describing curious laws and taboos surrounding gold, received a mixed welcome. Many of the travellers were accused of embellishing their observations, authoring accounts that had little to do with scientific investigations and the advancement of comparative knowledge (Howorth et al. 1894, Review 1925, Thevenet 1989:265). Although the authors emerged largely victorious from the formal hearings held at the time ${ }^{4}$, the stories from Inner Asia still remain strikingly marginal to regional scholarship (cf. Bawden 1985). This paucity is all the more surprising given the accounts' detailed insights into local ways of life, which more conventional historical material often leaves in silence. By focussing on some of these travellers' accounts, this article seeks to convey the kinds of narratives that emerged from the region and begin our exploration into the historical position of gold mining in Mongolia.

In 1841, the Lazarist missionaries Évariste-Régis Huc and Joseph Gabet were sent to explore a newly created apostolic vicariate on the Ordos plateau in today's Inner Mongolia ${ }^{5}$. They spent two years wandering through regions that were rich in precious metals such as gold and silver. One evening, when they made camp in a desolate region haunted by the presence of robbers and vagabonds, a story came to their minds. In the "kingdom of Ouniot", not far from where they camped, there was once a Chinese prospector who discovered a major gold vein ${ }^{6}$. Despite a "rigorous prohibition to work these mines" (Huc 1852:20), word of the abundant riches was quickly passed on and the area soon became home to thousands of fortune hunters. Whilst some of them worked in the mines, others pillaged surrounding areas. In the face of local people's protests, lawlessness reigned. This state of disorder culminated when the Queen of Ouniot had to pass through the "valley of gold", where she was held up and ordered to hand over her jewels.

Upon her return home she reproached the King bitterly for his cowardice. At length, stung by her words, he assembled the troops of his two banners and marched against the miners. The engagement which 
Pre-copyedited version! Final version published in Central Asian Survey 29(3): 289-304.

ensued was for a while doubtful, but at length the miners were driven in by the Tartar cavalry, who massacred them without mercy. The bulk of the survivors took refuge in the mine. The Mongols blocked up the apertures with huge stones. The cries of the despairing wretches within were heard for days and then ceased forever. Those of the miners who were taken alive had their eyes put out and were dismissed (ibid.:22-23).

This story describes in detail the punishment of miners, highlighting the interest and power of ruling families and their role in maintaining order. Formal and explicit prohibitions against mining not only existed, but were also cruelly enforced. Since fortune hunters, El Dorados, and quasi-mythical gold nuggets pervaded popular European imagination at the time, the prohibition against mining in such a sparsely populated and remote region perplexed the missionaries. Their detailed attention to the punishment of miners might have been further triggered by the possibility that the prohibitions could indicate local moral frameworks. Such insights were central to the work on the missions, especially the Lazarist vicariate that was founded only one year earlier and was under the order of the resident Bishop Mouly to gather information about the customs and beliefs of the people to be evangelized. Their accounts thus give careful attention to such transgressions, often noting the location of the mining, the origin of the miners and their received punishment. Interestingly, the miners are consistently described as non-locals. Given the harsh punishment, these migrant-miners were potentially unaware of local legal frameworks or proceeded undeterred by the risks of punishment. Indeed, such risks might not have appeared that great since, as demonstrated in this story, political authorities did not necessarily take immediate measures to close down the prohibited mines.

In some of the accounts, the miners searching for gold in the Mongolian region are specifically described as foreigners coming from other countries (e.g. Ossendowski and Stanton Palen 1924). In an account by a young Danish medical doctor Carl Krebs ${ }^{7}$, an old Buryat bear hunter entertained his foreign visitor with a story about how a Russian superintendent and his two Chinese labourers were murdered when mining for gold at a place where "evil spirits reign" (Krebs 1937:73) ${ }^{8}$.

Two young Buryats who often enjoyed a cup of tea with Jakob [the Russian superintendent] offered him a wild boar that they had just shot. It was lying a bit up the mountainside in the forest. When they had walked far enough away so that the shot could not be heard from the hut, they shot Jakob. Afterwards, they walked back down and shot the Chinese [assistant] who was washing gold by the river. Only the girl was left then. Instead of wasting cartridges on her, they stabbed her to death (Krebs 1937:73-74) ${ }^{9}$.

Like Huc and Gabet, Krebs was struck by the violent punishment of the miners (see also Ossendowski 1923). Rather than ignoring the miners' search for gold or awaiting the authorities' arrival, the local population appeared to take instant action and put a forceful end to the mining operations. The painful cries, the stabbing to death and the pulled-out eyes emphasized to Krebs the perceived gravity and severity of the foreigners' gold mining activities. Whilst such brutal confrontations between local populations and incoming miners might indicate a race to stake mining claims akin to gold rushes elsewhere, claims made by local prospectors are noticeably absent in the accounts. Indeed, quotidian mining carried out by locals appears strikingly nonexistent (see Prejevalsky 1876:58). Although this may be due to the genre of the accounts where violent confrontations might have made for more interesting and compelling reading, similar accounts from the same time period on neighbouring 
Pre-copyedited version! Final version published in Central Asian Survey 29(3): 289-304.

regions do contain elaborate details of mining carried out by locals (cf. Rockhill 1891:178, 208, 209, Weale 1904:ch. 9, Michie 1864:283-289, Littlepage and Demaree 1938) ${ }^{10}$. Rather than regarding this paucity as a mere product of the literary genre, we suggest that the accounts point to a Mongolian reluctance to engage in mining as well as an identification of mining with foreign encroachment ${ }^{11}$.

According to the Scottish missionary James Gilmour (1883), every time he dug a few stones of interest out of the ground, people became immediately suspicious and hostile towards him. He soon realized that they feared that he was searching for gold like so many other foreigners. If gold was mined, it would "take away the luck of the land" (ibid.:190). Living on "enchanted land", people regarded such actions as "a curse to the land and the people" (ibid.:255). This hostility not only concerned the act of mining, but also applied to other activities that involved digging into the ground, especially if carried out by outsiders. The British diplomat Charles W. Campbell notes in a memoir from 1903 that the Mongols were fearful of the noblemen's stone palaces and the foreigners' new houses that were cropping up in Ih Hüree (present-day Ulaanbaatar). The sturdy walls that rose tall and the deep foundations that sat permanently into the land lent the buildings an ominous presence. "Mongols believe that all these old palaces and cities are haunted, and that the spirits are prone to bring misfortune on intruders" (Campbell 1903:494).

Rather than relating to the land in terms of individual claims that justify the private ownership and use of the land, Mongols regarded the 'enchanted land' as an animate entity with fundamental implications for all aspects of human life. Failing to interact respectfully, curses were unleashed and misfortune was imminent. At a time when gold rushes spread across the world and the lure of gold attracted many a foreigner to the relatively unexplored region, mining operations were repeatedly brought to an end. Such closures convey not only an aversion towards mining, but also the ability of local populations to assert their own interests in the face of conflict. Although the miners were predominantly foreigners and their punishment often harsh, the travellers' accounts from the $19^{\text {th }}$ century do not generally portray the Mongols as violent or in any way xenophobic. Instead, they point specifically to mining as a contentious and pressing issue for local populations - much like it is today.

\section{The politics of a 'pure' land}

Whilst the travellers' accounts mostly describe the ways in which local populations tackled the issue of gold mining, archival sources offer insights into the imperial State's perspective. Specifically, this section will focus on the views and interests expressed by the men who ran the Qing government in Mongolia at the time. Although many of these documents are written in Manchu and some in Chinese, most of the writers used Mongolian for state affairs. This allows a certain Mongol voice to come through, if only that of elites.

In contrast to the centralized nation-states that emerged in its wake, the territorially and demographically immense Qing Empire had a relatively small governing apparatus. With a GovernorGeneral based in Uliastai and two imperial representatives (called ambans) in Ih Hüree (modern-day Ulaanbaatar), the presence in Mongolia of court-appointed officials was minimal. These officials kept 
Pre-copyedited version! Final version published in Central Asian Survey 29(3): 289-304.

in regular contact with the Board for Governing Outer Dependencies, which was an overseeing bureaucratic organ in Beijing $^{12}$. Rather than seeking centralized control, the Qing court relied heavily upon and aligned its interests with the Mongol noblemen (called jasa $\gamma$ ). This alliance between court and Mongol aristocracy was regularly affirmed through visits to the emperor in Beijing, collective hunting expeditions, and exchanges of gifts. During the many wars of imperial expansion, the court also rewarded those Mongol elites who were loyal to the Qing whilst punishing those who resisted with military action ${ }^{13}$. Most Mongol political communities, including the Halh, were given stature and power within the empire; others, including Cahars and Oirats, were not.

The court allocated its greatest endowments of wealth, prestige and authority to the jasays who were granted control over 'banners'. Banners were a Qing innovation, constituting a fundamental unit of the imperial military and a core jurisdiction for civil life. Within the banner, a jasa $\gamma$ had his own administration of clerks, police, guards, and other officials. Commoners paid taxes to and served corvée (their labour obligation) in the banner and if they committed a crime, they were tried at the jasa 's court $^{14}$. As a result of the banner system, Qing rule over Mongolia was less of a conquest of one nation over another than a set of regulated, hierarchical and personal relationships between the emperor and the Mongol noblemen ${ }^{15}$.

Whilst the imperial project attempted to incorporate individual Mongol elites into the state, it was also concerned with the protection of the "Mongol lands". The court considered Mongol lands vital to the flourishing of the empire, not least because it formed a critical line of defence against the powerful Dzungar (1678-1756) and Russian empires. Defending Mongol lands entailed the protection of the territorial boundaries of the banners as well as the so-called Mongol "way of life" (Ma: banjire doro). This "way of life" was seen to make the local populations distinct and had economic, environmental, genealogical, cultural and political dimensions. In the mid-19 ${ }^{\text {th }}$ century, aspects of a Mongol "way of life" specifically included the pursuit of steppe pastoralism, respect for the Dge-lugs-pa-school of Buddhism, and subjugation to banner and imperial authorities ${ }^{16}$. In order to ensure this protection, the Qing emperors sought to rule their Mongol constituency in an acceptably Mongol fashion, as khan and patron of Buddhism ${ }^{17}$.

Ideally, the Mongols and Mongol lands were to be untainted by foreign influences. Noblemen were forbidden from giving their children Chinese names ${ }^{18}$ and Chinese men were prohibited from taking Mongol wives ${ }^{19}$. In Halh Mongolia, non-Mongols lived in quarters that were gated off from the community around them: the Manchus lived in walled garrisons and the Chinese in "trade towns" (maimaicheng) governed by separate laws and administrative systems. Unless a permit was issued, no outsider could trespass banner land ${ }^{20}$. All who were found to have 'escaped' across a border were detained by banner authorities, interrogated and removed under escort to their home jurisdiction for further punishment. The number and diversity of such 'escapees' testify to the limitations of the imperial project. While Chinese migrants were arrested most often, the archives record the arrests of a striking range of fugitives: Russians, Bukharans, Tibetans and even Ottoman Turks - a reflection of a certain cosmopolitanism to Qing Mongolia ${ }^{21}$. Interestingly, the occupations of those who illegally 
Pre-copyedited version! Final version published in Central Asian Survey 29(3): 289-304.

entered Mongol lands included not just merchants, monks, mushroom pickers, farmers and slaves, but also miners.

Local officials justified these policing efforts in terms of an imperial responsibility to "purify the land" (Mo: yajar i arizun bol $\gamma-a$, Ma: babe bolgo obu) ${ }^{22}$. 'Pure' lands most often referred to lands free of illegal Chinese migrants: if Chinese were found to be 'mixing' with the local population or engaging in disruptive activities, the use of state intervention and, if necessary, force was deemed appropriate. Such disruptive activities included actions that rendered the land unfit for the proper Mongol way of life, for example over-logging, over-fishing, over-hunting or mining. If the perpetrators were caught, the area subsequently required purification. This entailed the arrest of the perpetrators, the establishment of guard posts (karun) and intensified policing of the threatened grounds. In every case, achieving 'purity' was considered 'of the utmost importance'. Mongol lands were thus a potentially fragile realm within which a prosperous and proper Mongol life could be pursued ${ }^{23}$.

While the Qing court positioned itself as the protector of the Mongols and their lands, it also made material claims to gold. In the early Qing conquests of the late $16^{\text {th }}$ and early $17^{\text {th }}$ centuries, gold was confiscated from defeated enemies and redistributed to loyal allies. Weapons and saddles inlaid with gold, gold coins, hairpins, necklaces, earrings, hatpins, buttons, and earrings flowed from the emperor to his clients ${ }^{24}$. In the late $18^{\text {th }}$ and $19^{\text {th }}$ centuries, a more peaceful form of 'gold diplomacy' helped reaffirm the relationship between emperor and subject. Gifts were exchanged, such as a golden lettered sutra from the Jebdzundamba Hutuktu to the Jiaqing Emperor in 1820 on his $60^{\text {th }}$ birthday, and, after his death, a golden leafed, trilingual order of imperial recognition was sent by the young Daoguang Emperor to the Jebdzundmba less than a year later ${ }^{25}$. Qing rulers also used gold ideologically to claim succession from the Chinggisids, the "Golden Khans" of the past. Gold was closely associated with ruling charisma in the Inner Asian ruling tradition and in classical Mongol texts, as Henry Serruys argued, "gold" symbolized "imperial" (Serruys 1962: 357). Chinggis Khan's lineage was known as the

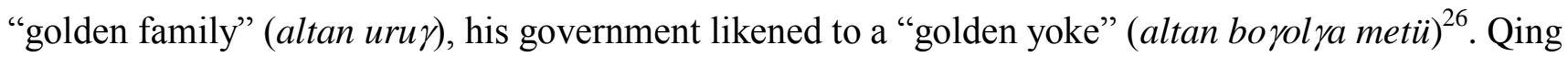
rulers, for their part, took their own "golden" family name (the "Golden" (Aisin) Gioro) and originally named their domain the "Golden State" (aisin gurun), before changing the name to Qing in $1636^{27}$. In Qing period chronicles written in Mongolian, 'gold' continued to have these associations with legitimate rule and the Chinggisids, with the "Golden" Gioro identified as part of the 'golden family'. Likewise, the Forbidden City took the name of the "Golden Palace" (Serruys 1962:359, 362) 28 , while the court conferred authority to the jasa $\gamma$ with golden seals (Mostaert 1935-1936:318) ${ }^{29}$.

The court made claims over regional products, such as horses, wild boars, and sables, all of which were exacted as tribute (alban) from various constituencies within Mongolia. Yet gold was treated differently. On the ground, Mongolian places known to contain gold were designated "restricted areas"

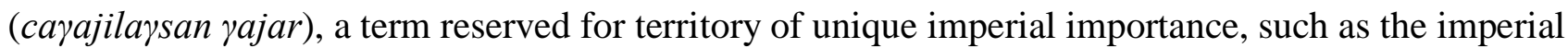
hunting grounds and the lands rich with sable on the border with Russia ${ }^{30}$. However, whereas restricted hunting grounds were designed, in part, to ensure a plentiful catch for state-organized hunts, restricted gold fields were never meant to be productive. When trespassing or mining occurred, policing was stepped up. In one such case, in 1830, the Governor-General of Uliastai reported that "impoverished, 
Pre-copyedited version! Final version published in Central Asian Survey 29(3): 289-304.

unemployed Chinese are crossing the border digging for gold sand"31. He requested two additional guard posts, each consisting of one captain and nine soldiers, to be established in the threatened area south of Uliastai. Thereafter, a total of 24 guard posts strung between Uliastai and Zuunmod were subject to special patrols, including annual inspections of their arsenals. If all remained secure, the guards had to vouch that "the mountain valleys which produce gold [saw] no illicit gold-digging and no sign of human activity" 32 .

While Chinese migrants were a problem, they were not necessarily the primary concern of the court. Indeed, the court was much more concerned with the conduct of the Mongols. This emphasis is vividly expressed in a publication from 1841, which is the first set of laws to specifically address gold mining in Mongolia in the Laws of the Board Governing Outer Dependencies, the normative touchstone for legal practice in Mongolia ${ }^{33}$. Replacing an earlier edition from 1826, which was silent on the issue of gold mining, the 1841 Laws of the Board conveys many of the anxieties of the intervening 15 years. Drought and disastrous weather $(z u d)$ was recorded for the years 1826-1827, 1835-1837, and 1840, and the impact on the pastoral economy was severe ${ }^{34}$. Under duress, it appears that many Mongols turned to a range of illicit activities, including gold mining ${ }^{35}$.

According to the revised Laws of the Board, banner authorities had responsibility for enforcing the prohibition on gold mining. If Chinese migrants broke the prohibition, the responsible official received a light fine (equal to one "ninth" of livestock), while the overseeing jasar lost three months pay. If, on the other hand, Mongols themselves had been mining gold, the punishment was twice as severe: the official was fired and the jasar lost six months pay. Worse still, if Mongols and Chinese had conspired to mine together, the official would not only be fired, but whipped 100 times, while the jasar was fined a full year's pay. Most serious of all was the wilful collusion between Mongols, Chinese and banner officials. In this final case, the official was not only fired and whipped, but forced to wear the cangue ${ }^{36}$ for a month, while the jasa $\gamma$ was fined two years' pay $^{37}$. The greater the violation of the proper Mongol 'way of life', the greater the punishment: Mongols mining for gold represented a greater transgression than Chinese who performed the same act, while Mongols who collaborated with Chinese were worse still. The identity of the miner was thus more significant than the act of mining in itself, the criminal more important than the crime.

In cases where Chinese were known to have broken the prohibition, officials were thus required to investigate and report on whether local Mongols were collaborating. In cases involving large numbers of migrants, the nobility's loyalty came into question. In 1782, Cebdenjab (an amban at Ih Hüree) reported that over 500 Chinese migrants were engaged in illegal gold mining within his jurisdiction. The Qianlong emperor (r.1735-1795) was exasperated and in his stern, personal reply he wondered openly if a Mongol was to blame: "The Halh live far from the interior. If Mongols are not seeking profit and soliciting [Chinese miners], how could the Chinese even know which places have gold and [where] to dig?"38

As the edicts suggest, mining in Mongolia was taking place at a significant level from at least the $18^{\text {th }}$ century on. Compared with today, its scope and intensity remained relatively limited. Yet the political 
Pre-copyedited version! Final version published in Central Asian Survey 29(3): 289-304.

challenge it posed was clear to all. News of uncontrollable foreigners, violence, and atrocities

surrounding mining circulated through all levels of society, from the local people who related terrifying stories to European travellers, to jasays, ambans, and the emperor himself, who responded with a newly elaborated prohibition. The call for 'purity' was also a response to these pressures. The aspirations embodied by the concept- clear boundaries between Mongols and Chinese, proper use of the land, and seamless functioning of the banner system - were inextricable from the sense of looming crisis. Boundaries were being blurred, the land was being scarred, and the banner system was failing to address the economic and political challenges of the $19^{\text {th }}$ century.

\section{The attraction of large-scale mining}

When mining was ultimately legalized, it was largely because Mongolia's strategic place in the empire had changed. In the late $19^{\text {th }}$ century, the Qing state was decimated by violent rebellions, fiscal crises, and aggression from imperialist powers. Following European, Russian, and North American models, a new generation of officials increasingly promoted industrial mining as indispensable to reconstruction and in 1889 the Qing government established its first state-run gold mine at Mohe, in northern Manchuria. The prohibition on gold mining in Mongolia ended just a decade later, in 1899, with the ceding of mineral rights to the Mongolor mining company. Yet the dramatic policy changes of the early $20^{\text {th }}$ century, on the eve of the empire's collapse, represented in many ways a culmination of a liberalization of mining policy that began almost two centuries prior, when Qing commercial and military strength was at its apex.

The early emperors had been generally opposed to opening mines anywhere in the empire, not just in Mongolia. If a county magistrate in the Chinese interior relayed upwards a request to open a new mine, potential profits were weighed unfavourably against social risks and the court invariably rejected the petition. For one, the local poor rarely seemed to benefit from mining. Instead, new mines only attracted migrant workers - young, unmarried men, without family or farm, who were prone to rabblerousing, licentiousness, and violence (Kuhn 1990, Sommer 2000). In China, these social concerns were matched by an equal desire to protect gravesites from disruptive digging and preserve the geomantic qualities of the environment - in Chinese, its fengshui ${ }^{39}$.

However, from the mid- $18^{\text {th }}$ century some of the empire's most eminent statesmen began to argue that mining policy had grown out of touch with the demographic and economic reality on the ground, particularly in China's agricultural core. The population of the empire tripled in the years 1700-1850 alone (Lee 1982:743). Migrant workers seemed to be arriving in towns and villages like never before (Kuhn 2008:12-25). At the same time, demand for natural resources and precious metals was booming and opportunities to illegally mine abounded. With illegal mining running riot and eminent statesmen calling for reform, the court gradually began liberalizing mining policy. If merchants provided start-up capital and local authorities assured law and order, the court would be willing to endorse the effort ${ }^{40}$.

In a few special cases, the court even allowed limiting mining ventures in Mongolia. Gold mining was briefly legalized, for example, in Alashan, an Inner Mongolian banner bordering the Chinese interior. The ruling prince of Alashan, Lobsangdorji. spearheaded the effort. In the winter of 1756-1757, he first 
Pre-copyedited version! Final version published in Central Asian Survey 29(3): 289-304.

reported that illegal Chinese migrants were digging for gold in the pasturelands of local Mongol herders. When banner forces attempted to drive the miners out, they resisted with hoes and axes ${ }^{41} .16$ years later, in the winter of 1772-1773, illicit mining was still an issue and Lobsangdorji felt obliged to raise the matter with the emperor himself while on a court visit to Beijing ${ }^{42}$. After an investigation by the Grand Council, troops were dispatched and more than 100 miners were captured and arrested. However, Prince Lobsangdorji was more interested in controlling the miners than driving them out ${ }^{43}$. In 1774 he proposed a plan to organize the miners himself, with the men divided into work units of ten and each unit compensated with double the weight in silver for all gold produced ${ }^{44}$. Shortly after, the plan was approved and mining was legalized at the site. Chinese merchant houses quickly raised capital for the operation and a Chinese administrator was charged with immediate oversight of the miners ${ }^{45}$. For the privilege of using his land, Lobsangdorji would be compensated with one-third of the generated revenue. Upon its opening, the operation quickly boomed with an estimated 2000 miners producing 352 silver taels ${ }^{46}$ worth of gold. Just three years later in 1777 , however, the gold deposits were effectively depleted and the miners produced a mere nine taels worth of gold - a staggering bust ${ }^{47}$. Capital investment dried up and mining at the site was again prohibited ${ }^{48}$.

A similar arrangement was set up more than 100 years later when Mongolia's first industrial mines, under the direction of the new mining company Mongolor, were finally permitted to open. Mongolor was distinctive, in part, for being a Western-style joint-stock company. Instead of merchants from north China, start-up capital was offered by Victor van Grot, who was an ambitious Russian officer in the customs house at Tianjin, in exchange for open access to Outer Mongolia.

The Mongolor proposal triggered a high-level debate at court, involving the emperor, top bureaucrats in Beijing, and the amban in Ih Hüree, with the amban responsible for assuring consent from the Mongol nobility (Ch: wanggong) to any contract with van Grot ${ }^{49}$. The welfare of Mongols was discussed, with those in favour of the proposal arguing that industrial mining would put Mongolia's resources to use and alleviate widespread poverty ${ }^{50}$. The topmost concern, though, was the security threat posed by Mongolor's foreign backing. To those opposed to the plan, any foreign presence in Mongolia was unacceptable. They argued, for example, that the completion of the China Eastern Railway, the fareastern leg of the Trans-Siberian railroad that traversed Qing Manchuria, had given Russia dangerous leverage in the northeast ${ }^{51}$. Those in favour dismissed such concerns by pointing to the successful operation of foreign-financed railways in northern China, asking defiantly "why only in [the jurisdiction of] Ih Hüree there are obstructions" to such successful modernization schemes ${ }^{52}$. Was Mongolia like Manchuria, a vulnerable frontier, or more like China itself, without need for any special treatment?

The formal approval of the plan and the start of mining operations in 1899 suggest the answer at court. Mining machinery was sent at great expense from Europe and the contracting of workers began. Since the mining contract explicitly stated that Russians were to be excluded from the labour force in favour of Chinese and (it was hoped) destitute Mongols, Mongolor sought to hire locally. But it turned out to be a challenge. According to Frans Larson ${ }^{53}$, who worked with van Grot between 1900 and 1902, the Mongols refused to work in the mines (see also Montagu 1956) ${ }^{54}$. 
Pre-copyedited version! Final version published in Central Asian Survey 29(3): 289-304.

There was plenty of gold in the locality. The Mongols looked on interestedly at the work, but did not cooperate in it. Digging great quantities of gold out of the earth did not appeal to the Mongol as a profitable way in which to spend his days. Labourers had to be imported. We got some Russians, but most of our workers were Chinese coolies who came from Shantung (Larson 1930:245-246).

Due to the high political tensions between the Qing and Russian governments, the arrival of Russian migrants to the Mongolor mines strained the political goodwill for the mining venture that was meant to bring some much needed capital for the state budget ${ }^{55}$. Also, the local population demanded the mines to be closed and the political rulers began to fear that they were "losing the Mongols" hearts" 56. In order to keep migrants out of the area, they therefore reinstituted the prohibition against outsiders mining in Tusiyetu and Cecen Han aimags ${ }^{57}$. However, given mounting concerns it was finally decided that the mines should close and they were not reopened until 1908 when a restructured agreement with higher percentages allotted to the Qing government and the Mongol noblemen was agreed. A spate of mining camps were officially established at Zhuerhupo in 1906, Gudala in 1908, Gugongtai in 1909, Halagenang in 1910, Kuiteng in 1911 and Yarbink in 1911 (Kadokura 1936:391). The boom climaxed in 1911, the year of Mongolia's independence from the Qing Empire, but sharply declined shortly after. According to Russian archival sources, van Grot was ruined by debt and ultimately forced to flee to America "without a penny to his name (..) as a common labourer" (Romanov 1952 [1928]:510). The many years of local protests and renewed negotiation had drained the investors' finances. Telegrams were sent abroad, alerting international banks and financiers of the fiasco. The enthusiastic reports that prospectors had sent home were eclipsed by cautionary tales of van Grot's trials with the Mongols and his complete bankruptcy.

The lure of gold that had repeatedly taken miners to the Inner Asian lands was once again stifled by the local population's ability to contribute to the actual closures of mining operations. However, in contrast to the scenarios described in the travellers' accounts, local populations were now protesting again mining carried out at an industrial-scale. Moreover, the new mining operations enjoyed the full endorsement of the court officials who had eyed a profitable new path for the generation of muchneeded state revenue. And, as hinted at in the archival material, this endorsement was likely to be shared by at least some of the local population. By considering both the travellers' accounts and the archival material, it becomes clear that the politics of gold mining were not simply a black and white scenario with the court and the Mongol people consistently positioned in opposition. The politics of gold mining for the Qing court centred around the challenge of conciliating modern mining with the continued relevance among people for a certain Mongol 'way of life'. Even if the 'pure' land was no longer an imperial category for environmental preservation and land control, it remained an important category to large parts of the population. Positioned centrally between increasingly diverging interests, the purity and exclusivity of the 'enchanted land' was a concern that, for many Mongols, extended far beyond the political and economic aspirations of the Qing court.

\section{Conclusion}

In April 2006 several hundred protestors took to the streets of Ulaanbaatar to protest against alleged government corruption and the mishandling of mineral wealth in Mongolia. Effigies of the country's 
Pre-copyedited version! Final version published in Central Asian Survey 29(3): 289-304.

then President, the Speaker of Parliament as well as mining-tycoon Robert Friedland were set on fire, whilst protestors held an extended hunger strike in the city's central square. The protestors demanded that the government change its terms of negotiation with the company Ivanhoe Mines and insisted on terms more favourable to the country's population. The demonstrators wanted Mongolia to retain a majority ownership of the mineral deposit, which was owned by a company that brought with it an extensive portfolio of environmental disasters and a generous concern for its shareholders ${ }^{58}$. Alongside protests against formal sector mining, civil movements also deplored the environmental and social consequences of the still growing gold rush. The gold fever had arrived in Mongolia and demonstrators were furious at the lure of gold that spread to both companies and individual miners. Prospecting and protesting was not only a theme of the Qing period, but also in Mongolia today.

The protests documented in archival material and the accounts of travellers reflect a recurrent concern with the 'purity' of the landscape. Missionaries who take stones from the ground are met with hostility, while foreigners who dig for gold are punished brutally. Qing emperors prohibit practices of gold mining and sternly enforce the laws if disregarded. The land is to be kept 'ariun', protected from disturbing foreign presences. Mongolian protestors who today take to the streets of Ulaanbaatar raise concerns about the resilience of a fragile landscape. In response to companies re-directing rivers and gold rush miners converting the steppe into moon-like craters, they question whether the land will be able to continue sustaining its inhabitants. Concerns about the relationship between people and places have a long history. The idea that the land requires human care and protection is not new to Mongolia nor is it merely an instrumental response to current realities. In this article we hope to have shown that 'baigal' is not only a powerful political currency of the present, but a long-standing reality for the Mongols.

Emperors, governors and other political rulers have been central to both the protection of Mongol lands and the acquisition of its mineral wealth. Yet, repeated attempts at regulation and policing have not managed to curb the spellbinding attraction of gold. Spurred on by broader economic, demographic and social processes, Chinese migrants ventured to Qing Mongolia in search of this precious metal. Mongolian noblemen used their position of political autonomy to set up independent mines, disregarding the emperors' prohibitions. The current politics of gold mining in Mongolia evokes similar historical dynamics between rulers and rascals. Even today, thousands of people are mining for gold outside the purview of State law - except this time the rascals are Mongols themselves. Qing regulations held Mongols to a higher standard of conduct than Chinese. When Mongols defied taboos on mining, the stakes were higher - and they were never higher than when gold was involved. Gold was historically a key constituent in the representation of political power. Enshrined in legal codes, gold was meant to flow upwards to the ruler, to sustain and display his position. As Mongolia's first ever official gold rush is today debated by members of parliament, this verticality is being challenged. The current gold rush is producing gold that lies outside the reach of the Bank of Mongolia, outside the regulation of the Cadastre Office, and outside the official production tables of the country. Today's gold rush is producing a kind of gold that truly is new. 
Pre-copyedited version! Final version published in Central Asian Survey 29(3): 289-304.

The history of Mongolia shares much with other gold-rush nations of the $19^{\text {th }}$ century. Globally, the era was marked by an unprecedented degree of cross-border movement, displacement, and migration, unfolding amidst renewed efforts to harden boundaries and define nations. Indeed, the same pulse that first brought migrant miners to the Mongol lands brought the same men to contemporary gold rushes across the world, from California and Australia, to British Columbia, Siberia, and South Africa ${ }^{59}$. In each case, exclusion laws ultimately followed the rush to the gold fields. The drive for the "purification" of Mongolia was thus not wholly unique. However, with miners and exclusion laws arriving a full century in advance, Mongolia was ahead of the curve. The types of anxieties it confronted were what others around the world confronted at a later date. Yet, in contrast to the classic gold rush nations, the Mongolian politics of exclusion were not driven by anti-immigration acts against Chinese miners or concerted attempts to exclude migrant labourers from an emerging labour aristocracy. It was rather a complete rejection of mining specifically. In a world that is still turned literally upside down in the search for gold, Mongolia is again in the midst of a battle over its mining. 
Pre-copyedited version! Final version published in Central Asian Survey 29(3): 289-304.

\section{Bibliography}

\section{Unpublished and archival material}

Hesei toktobuha tulergi golo be dasara jurgan i kooli hacin i bithe, 1841 (referred to as KHB).

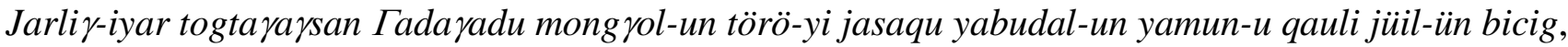
1826.

Mongolian National Central Archives, Fond M1D1, Office of the Amban at Ikh Khüree (referred to as MNCA).

Mongolian National Central Archives, Fond M2D1, Office of the Governor-General at Uliastai (referred to as MNCA).

\section{Published material}

Allsen, T., 1997. Commodity and Exchange in the Mongol Empire. New York: Cambridge University Press.

Atwood, C.P., 2000. 'Worshipping Grace': The Language of Loyalty in Qing Mongolia. Late Imperial China 21 (2), 86-139.

Bawden, C.R., 1968. The Modern History of Mongolia. New York: Frederick A. Praeger.

Bawden, C.R., 1985. Shamans, Lamas and Evangelicals: The English Missionaries in Siberia. London: Routledge and Kegan Paul.

Boldbaatar, Z., 2002. Mongolchuudyn Bařgal' Orchnoo Hamgallah Zan Zanwhil, Huul' Togtoomhilǐn Höghliǐn Tuuhen Toǐm. Tuuh: Erdem Shinzhilgeeniǐ Bichig 188 (14), 80-98.

Campbell, C.W., 1903. Journeys in Mongolia. The Geographical Journal 22 (5), 485-518.

Carruthers, D., 1913. Unknown Mongolia: A Record of Travel and Exploration in North-West Mongolia and Dzungaria. London: Royal Geographical Society.

Chan, H.-L., 1991. 'Ta Chin' (Great Golden): The Origin and Changing Interpretations of the Jurchen State Name. T'oung Pao 77 (4/5), 253-299. 
Pre-copyedited version! Final version published in Central Asian Survey 29(3): 289-304.

Clements, J.M., 1922. Gold Placer Area in Mongolia, China. Department of Commerce Bureau of Foreign and Domestic Commerce: Trade Information Bulletin No.4, Far Eastern Division.

Washington: Government Printing Office.

Cronon, W., 1996. The Trouble with Wilderness; or, Getting Back to the Wrong Nature. In W. Cronon, ed. Uncommon Ground: Rethinking the Human Place in Nature. New York: W.W. Norton and Company.

Crossley, P.K., 1999. A Translucent Mirror. Berkeley: University of California Press.

Duara, P., 1995. Rescuing History from the Nation: Questioning Narratives of Modern China. Chicago: University of Chicago Press.

Elverskog, J., 2006. Our Great Qing: the Mongols, Buddhism and the State in Late Imperial China. Honolulu: University of Hawaii Press.

E-Tu, Z.S., 1967. Mining Labor in the Ch'ing Period. In A. Feuerwerker, R. Murphy and M. Wright, eds. Approaches to Modern Chinese History. Berkeley: University of California Press.

Eichengreen, B. and McLean, I.W., 1994. The Supply of Gold under the Pre-1914 Gold Standard. Economic History Review 47 (2), 288-309.

Elliott, M.C., 2001. The Manchu Way. Stanford: Stanford University Press.

Farquhar, D.M., 1960. The Ch'ing Administration of Mongolia Up to the Nineteenth Century. Thesis (PhD). Harvard University.

Gagengaowa and Wuyunbatu, 2003. Menggu Minzu de Shengtai Wenhua. Hohhot: Neimenggu Jiaoyu Chubanshe.

Gao Wangling, 1993. Guanyu Qingdai Kuangzheng de Jige Wenti. Qingshi Yanjiu. 3, 20-22.

Gilmour, J., 1883. Among the Mongols. London: Religious Tract Society.

Haslund-Christensen, H., 1934. Tents in Mongolia (Yabonah): Adventures and Experiences among the Nomads of Central Asia. London: Kegan Paul.

Heuschert, D., 1998. Legal Pluralism in the Qing Empire: Manchu Legislation for the Mongols. The International History Review 20 (2), 310-324.

High, M.M., 2008. Dangerous Fortunes: Wealth and Patriarchy in the Mongolian Informal Gold Mining Economy. Thesis (PhD). University of Cambridge. 
Pre-copyedited version! Final version published in Central Asian Survey 29(3): 289-304.

High, M.M., forthcoming. The Cultural Logics of Illegality: Living Outside the Law in the Mongolian Gold Mines. In J. Dierkes, ed. Contemporary Mongolia: Transitions, Development and Social Transformations. Leiden: Brill Publishers.

Howorth, H., et al., 1894. A Journey in Mongolia and in Tibet: A Discussion. The Geographical Journal 3 (5), 385-388.

Huc, A., 1852. Travels in Tartary and Thibet. Vol. III. London: Herbert Joseph Limited.

Humphrey, C. and Sneath, D., 1999. The End of Nomadism? Society, State and the Environment in Inner Asia. Cambridge: The White Horse Press.

ILO, 2004. Baseline Survey on Informal Gold Mining in Bornuur and Zaamar Soums of Tuv Aimag. Ulaanbaatar: International Labour Organisation, Mongolian Employers' Federation, and Population Teaching and Research Center.

Irick, R.L., 1982. Ch'ing Policy Toward the Coolie Trade, 1847-1878. Taipei: Chinese Materials Center.

Kadokura, M., 1936. Hokuman Kinkō Shigen: Gaimōko Kinkō Shigen, Shinkyō Kinkō Sekiyu Shigen. Tokyo: Maruzen.

Krebs, C., 1937. En Dansker i Mongoliet - Den Vide Verden og Den Grønne Skov. København: Berlingske Forlag.

Kuangwu Dang, 1960. Taipei: Zhongyang Yanjiuyuan Jindaishi Yanjiusuo.

Kuhn, P., 1990. Soulstealers: The Chinese Sorcery Scare of 1768. Cambridge: Harvard University Press.

Kuhn, P., 2008. Chinese Among Others: Emigration in Modern Times. New York: Rowman \& Littlefield Publishers, Inc.

Larson, F.A., 1930. Larson - Duke of Mongolia. Boston: Little, Brown and Company.

Lee, J., 1982. Food Supply and Population Growth in Southwest China, 1250-1850. The Journal of Asian Studies 41 (4), 711-746.

Lee, R.H.G., 1970. The Manchurian Frontier in Ch'ing History. Cambridge: Harvard University Press. 
Pre-copyedited version! Final version published in Central Asian Survey 29(3): 289-304.

Legrand, J., 1976. L'Administration dans la Domination Sino-Mandschou en Mongolie Qalq-a:

Version Mongole du Lifan Yuan Zeli. Paris: College de France, Institut des Hautes Etudes Chinoises.

Littlepage, J. and Demaree, B., 1938. In Search of Soviet Gold. London: Harcourt, Brace \& Co.

Manbun Rōtō, 1955. Tokyo: the Toyo Bunko (referred to as MBRT).

Michie, A., 1864. The Siberian Overland Route: From Peking to Petersburg Through the Deserts and Steppes of Mongolia, Tartary, etc. London: John Murray.

Montagu, I., 1956. Land of Blue Sky - A Portrait of Modern Mongolia. London: Dennis Dobson.

Mosca, M.W., 2010. Empire and the Circulation of Frontier Intelligence: Qing Conceptions of the Ottomans. Harvard Journal of Asiatic Studies 70 (1), 147-207.

Mostaert, A., 1935-36. L' 'Ouverture du Sceau' et les Addresses chez les Ordos. Monumenta Serica 1, 315-337.

Ossendowski, F., 1923. Beasts, Men and Gods. London: Edward Arnold.

Ossendowski, F. and Stanton Palen, L., 1924. Man and Mystery in Asia. London: Edward Arnold.

Perdue, P.C., 2005. China Marches West. Cambridge: Harvard University Press.

Preobrazhensky, A., 1993a. The Russian Pioneering of Siberia. International Affairs. 39 (4), 128-153.

Preobrazhensky, A., 1993b. The Beginning of a Common Road. International Affairs. 39 (5), 143-147.

Prejevalsky, N.M., 1876. Mongolia, the Tangut Country and the Solitudes of Northern Tibet: Being a Narrative of Three Years' Travel in Eastern High Asia. Translated by E.D.Morgan. London.

London: Sampson Low, Marston, Searle and Rivington.

Qingdai de Kuangye, 1983. Beijing: Zhonghua Shuju.

Qing Shilu, 1986 [reprinted edition]. Beijing: Zhonghua Shuju.

Review, 1925. The Ossendowski Controversy: Review. The Geographical Journal. 65 (3), 251-254.

Richardson, P., 1982. Chinese Mine Labour in the Transvaal. London: Macmillan Press.

Rockhill, W.W., 1891. The Land of the Lamas: Notes of a Journey Through China, Mongolia and Tibet. London: The Century Company. 
Pre-copyedited version! Final version published in Central Asian Survey 29(3): 289-304.

Rockhill, W.W., 1894. Diary of a Journey Through Mongolia and Tibet in 1891 and 1892. Washington DC: Smithsonian Institution.

Romanov, B.A., 1952 [1928]. Russia in Manchuria (1892-1906). Ann Arbor, MI: J.W. Edwards.

Rowe, W.T., 1982. Review Article: Recent Writing in the People's Republic on Early Ch'ing Economic History. Ching-shih wen-t'i 4(7), 77-81.

Schlesinger, J., Forthcoming. Inventing Nature in the Qing Empire. Thesis (PhD). Harvard University.

Sédillot, R., 1974. Histoire de l'Or. Paris: Fayard.

Serruys, H., 1962. Mongol Altan 'Gold' = 'Imperial'. Monumenta Serica 21, 357-378.

Serruys, H., 1977. The Office of Tayisi in Mongolia in the Fifteenth Century. Harvard Journal of Asiatic Studies 37 (2), 353-380.

Siegelbaum, L.H., 1978. Another 'Yellow Peril': Chinese Migrants in the Russian Far East and the Russian Reaction before 1917. Modern Asian Studies 12 (2), 307-330.

Sneath, D., 2007. The Headless State: Aristocratic Orders, Kinship Society, and Misrepresentations of Nomadic Inner Asia. New York: Columbia University Press.

Sommer, M., 2000. Sex, Law, and Society in Late Imperial China. Stanford: Stanford University Press.

State Ih Hural of Mongolia, 2006. Mongol Ulsyn Huul Ashigt Maltmalyn Tuhai, Shinechilsen Nairuulga. Ulaanbaatar: 8 July 2006.

Taveirne, P., 2004. Han-Mongol Encounters and Missionary Endeavours: A History of Scheut in Ordos Mongolia (Hetao) 1874-1911. Leuven: Leuven University Press.

Thevenet, J., 1989. Le Lama d'Occident: Evariste Huc, 1813-1860: De France en Tartarie et du Tibet en Chine. Paris: Seghers.

Tseren, P.B., 1996. Traditional Pastoral Practice of the Oirat Mongols and their Relationship with the Environment. Inner Asia 2, 147-157.

Wall Street Journal, 2007. Big Dig: Mongolia is Roiled by Miner's Huge Plans. 4 January 2007. Patrick Barta and Jargal Byambasuren. 
Pre-copyedited version! Final version published in Central Asian Survey 29(3): 289-304.

Weale, B.L.P., 1904. Manchu and Muscovite: Being Letters from Manchuria Written During the Autumn of 1903, with an Historical Sketch Entitled "Prologue to the Crisis". London: Macmillan.

Wei Qingyuan and Lu Su, 1981. Youguan Qingdai Qianqi Kuangye Zhengce de Yichang Dalunzhan. Beijing: People's University occasional paper.

Worden, R.L. and Savada, A.M., 1991. Mongolia - A Country Study. Washington DC: US Government Printing Office.

World Growth Mongolia, 2009. An Analysis of Concerns about the Draft Agreement to Undertake the Oyu Tolgoi Mining Project.

Wu Feng and Bao Qingde, 2009. Mengguzu Shengtai Zhihui Lun. Shenyang: Liaoning Minzu Chubanshe.

Yen Ching-hwang, 1985. Coolies and Mandarins: China's Protection of Overseas Chinese during the Late Ch'ing Period (1851-1911). Singapore: Singapore University Press.

Yule, H., 1876. Introductory Remarks. In N. Prejevalsky, Mongolia, The Tangut Country and the Solitudes of Northern Tibet: Being a Narrative of Three Years' Travel in Eastern High Asia, Vol. 1. Translated by E.D.Morgan. London: Sampson Low, Marston, Searle and Rivington.

\section{Notes}

This article is based on ethnographic and archival research carried out in Mongolia, China, Germany, Unites Kingdom and United States of America. For M.M.High, the research and writing has been supported primarily by an Economic and Social Research Council (ESRC) Postgraduate Studentship (PTA-030-2003-00784), Wenner-Gren Dissertation Fieldwork Grant (Gr. 7376) and a British Academy Post-Doctoral Fellowship (PDF/2009/423). For J. Schlesinger, support has been provided by the American Center for Mongolian Studies Research Fellowship, the Frederick Sheldon Travelling Fellowship (Harvard University), and the Fulbright-Hays Doctoral Dissertation Research Abroad (DDRA) fellowship.

${ }^{1}$ Corresponding author. Email: M.M.High@1se.ac.uk (note, from 1 Sep 2012: M.High@ed.ac.uk)

${ }^{2}$ The mining sector was of minimal proportion compared to today. During the socialist period the largest mine was the Erdenetiin-ovoo copper-molybdenum deposit, which went into operation in 1978. Following its development, mining 
production grew suddenly and accounted for 42.6 percent of all exports by 1985 (Worden and Savada 1991:141). However, since the Gross Domestic Product of 1985 was less than half of its present level, the mining sector was still comparatively small.

${ }^{3}$ Since Mongolia's National Central Archives are now largely open for researchers, there is a wealth of material available for reassessing the significance of the Qing period.

${ }^{4}$ Although many of these accounts were written in the name of investigative science, they were not necessarily assumed to be strictly truthful. However, given disputes such as those of Huc's observations (Prejevalsky vs. Yule in Yule 1876), Ossendowski's publications (Review 1925) and Rockhill's prose (Howorth et al. 1894), it is clear that the travellers were writing in a genre that, whilst enjoying some literary liberties, was still subject to rigorous critique.

${ }^{5}$ For more information on the history and fate of the Lazarist mission among the Mongols, see in particular Taveirne (2004:204-258).

${ }^{6}$ The author is likely to refer to Ongnuud Banner, which is a district in today's Inner Mongolia under the administration of Chifeng city (Ulanhad).

${ }^{7}$ Arriving in 1923, Carl Krebs led a small Danish expedition to Erdenebulgan sum in present-day Hövsgöl aimag where they sought to establish and run a permanent farming settlement. Due to pressure from the authorities, most of the team had to leave Mongolia in 1929 and in 1936 Carl Krebs finally left.

${ }^{8}$ See Carruthers (1914:167-168) for more detail on the gold fever in this area. For elaboration on the particular incidence discussed here by Krebs, which took place at Riefestahl's gold mine Sarhoi, see Haslund-Christensen (1934:4-6, 325-326).

${ }^{9}$ This excerpt is originally written in Danish and is here translated by M.M. High.

${ }^{10}$ Artisanal gold mining in Tibet was common, but the rewards were minimal. A local saying captures well its toil: "When a man has tried in vain to make a livelihood by every conceivable method, he finally takes to gold-washing" (Rockhill 1891:46). In Siberia locals were also involved in gold mining, but in contrast to Tibet the majority of the mining seems to have been formalised. The mining in Siberia was thus generally carried out by small co-operations, international companies and forced labourers in government-owned camps.

${ }^{11}$ This is not exclusive to Mongolia. Accounts describe, for example, how artisanal gold mining in Tibet existed amidst local perceptions of its wrongfulness. According to Rockhill: "Mining is not allowed in Tibet, as there exists a deep-rooted superstition, carefully fostered by the lamas, that if nuggets of gold are removed from the earth no more gold will be found in the river gravels, the nugget being the roots or plants whereof the gold dust is the grains or flowers" (1891:209).

${ }^{12}$ For a full description of the administrative structure of Qing Mongolia, see Farquhar (1960).

${ }^{13}$ The wars included Manchuria and Eastern Mongolia in 1593-1634, Ming-China in 1644-1681, Halh Mongolia in 1691, Tibet in 1721, and Western Mongolia and Dzungaria in 1757.

${ }^{14}$ Through the $18^{\text {th }}$ century, Mongol legal precedents served as the basis for judicial proceedings. See Heuschert (1998:310324) and Farquhar (1960:77).

${ }^{15}$ The narrative of Manchu rule and oppression of Mongols is standard in the nationalistically oriented, $20^{\text {th }}$ century historiography of the period. For a more nuanced discussion of Mongol participation in the Qing state and their reception of Qing ideology, see Elverskog (2006). For broader critiques of retrospective national narratives in Qing history, see Crossley (1999), Duara (1995), and Elliott (2001).

${ }^{16}$ The terms by which perceived differences were construed between Manchus, Mongols, and Chinese, their changes over time and the degree to which they constituted "ethnic" differences are much debated. For the two key voices in this debate, see Crossley (1999) and Elliott (2001).

${ }^{17}$ Ideologically, only the emperor, as the universal sovereign, ruled simultaneously as the ideal elite of each constituency, whether as Confucian scholar, Manchu warrior, or Manjushri, the bodhisattva of wisdom. See Crossley (1999). In practice, the Chinese, Manchu, and Mongol languages of rulership were often identical. See Atwood (2000).

${ }^{18} \mathrm{KHB}$ (53.15a-b). The rule applied to men holding the noble ranks of jasa , khan, wang, beile, beise, gung, taiji, and tabunang.

${ }^{19}$ KHB (25.28a-29a). Home jurisdiction defined one's ethnicity according to this prohibition. The law specifically addressed "Chinese from the interior" (dorgi ba i irgese) and "Mongol women from lands belonging to the jasajs of Inner and Outer Mongolia" (dorgi tulergi jasak I jergi ba I monggo hehe). In practice, the crime was forgiven if no one complained. For elderly couples, wives could even accompany husbands to the Chinese interior upon his final retirement. See MNCA M1D1.3822.48a. For a registry listing a group of intermarried couples living in Ih Hüree in 1824, see MNCA M1D1.844.

${ }^{20}$ For text of the laws, see "jecen de fafularangge" in KHB (34; 53.9a-10b). Restrictions on mobility went both ways, as the laws also specified that Mongols could not privately cross the border into the Chinese interior.

${ }^{21}$ For recent treatments of cross-cultural elements of Qing political culture see Atwood (2000) and Mosca (2010).

${ }^{22}$ Manchu-language texts consistently use the term bolgo to translate arizun; there was no consistent Chinese translation, though "qing" (pure; translucent - as in "Qing" Empire) was most common.

${ }^{23}$ For a fuller discussion of arifun and environmental politics in Qing Mongolia, see Schlesinger (Forthcoming: Chapter 4). 
Pre-copyedited version! Final version published in Central Asian Survey 29(3): 289-304.

${ }^{24}$ MBRT, passim.

${ }^{25}$ MNCA M1D1.4079.57. Gold also found its way into the earliest diplomatic occasions, with the ceremony of drinking spirits from a golden cup. See MBRT (1.3.36, 1.12.186, 1.24.349, 2.19.253, 2.25.332, 2.29.395, 2.34.467, 2.40.500, 2.43.593, 2.45.662, and 3.28.1295).

${ }^{26}$ For a fuller list of examples of gold in imperial ideology and material culture, see Serruys (1962) and Allsen (1997:60-70). The Chinggisids were neither the first nor last in the tradition. Examples of "gold" in imperial titles range from the first Turkish khanate $\left(6^{\text {th }}\right.$ century AD), to those of the Uighurs $\left(8^{\text {th }}-9^{\text {th }}\right.$ centuries), Altan Khan (1507-1582), the Özbek Khans, and even the Ming emperors, who were given the title by some allied Mongols as a sign of high respect. Thomas Allsen argues that the goldas-imperial tradition was distinctly "nomadic", with the Jin and Qing emperors excluded from the tradition on grounds that "the Jurchens were not nomads, but forest peoples whose political tutors were the Chinese" (1997:63). In this article, the authors maintain that the meaning of gold was multifaceted and historically variable.

${ }^{27}$ The name "Golden state," (aisin gurun) was a nod to another "Golden state", namely China's Jin dynasty (1115-1234), which the Manchus considered ancestral. In English, the name of the 'golden' dynasties is usually given as "Jin" Dynasty and "Later Jin Dynasty," using a Romanization of Chinese. Dynastic titles in Manchu were also transliterated from Chinese (Dai Yuwan for the "Great Yuan", Dai Ming for the "Great Ming" and there own Dai Cing). The two "Golden" dynasties, though, were different: they were always rendered with the Manchu word for "gold," aisin, suggesting its unique significance to Manchus. On meanings of "golden" in the Jin period, see Chan (1991). To the Manchu "Golden" khans, "golden" suggested heavenly favour and moral legitimacy (MBRT 2.17.226). The founder of the Manchu dynasty, Nurhaci, thus spoke of a proper "golden way" of khans (MBRT (1.3.28; 1.74.1102).

${ }^{28}$ Golden Palace is common to archival records; see MNCA M1D1.3416.1a (JQ10.8); MNCA M2D1 174.3a (DG6.2.5); MNCA M2D1.174.55b (DG6.12.1); MNCA M2D1.176.28a (DG12); MNCA M2D1.176.48a (DG14.12.27). Similarly, in 1628, the Tusiyetu Khan showing allegiance to the Manchu court by "prostrating himself before the golden visage of the Khan." See MBRT (2.14.191).

${ }^{29}$ Compare with the "golden seal" issued by the Ming dynasty in 1446 to Esen (Serruys 1977:361) and the Ming "gold tablet system" (jinpai xinfu), in which gold tablets were issued to Mongol leaders that granted trading privileges with the Ming court (Perdue 2005: 69).

${ }^{30}$ The phrase seems to have been used more in Mongol language documents than in Manchu language documents on

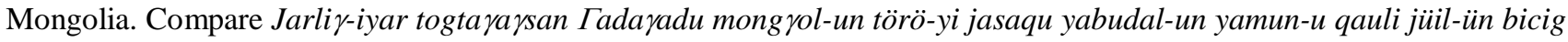
(5a-b) and KHB (53.5a-6a). Efforts to protect gold were similar to those to protect silver and furs. For the explicit linking of silver, gold, sable, and otter pelts, see MNCA M1D1-3350.32a.

${ }^{31}$ Qingshi lu (DG173.681.2-682.1).

${ }^{32}$ See MNCA M2D1-174.54b; MNCA M2D1-176-33b; and MNCA M2D1-176.81b. The messages were sent to Beijing on Dec. 29,1826 , Oct. 24, 1834, and July 1835, respectively; the emperor personally noted having read them each about three weeks later.

${ }^{33}$ The law also introduced regulations on silver mining. The punishment for mining gold and silver were identical.

${ }^{34}$ Catalogue, MNCA M1D1 archives.

${ }^{35}$ Other trades in natural resources, such as fur and elk antlers (used in Chinese medicine), also spiked during these years. See Schlesinger (Chapter 3). The Laws of the Board of 1841 also contain the first laws against opening distilleries and liquor shops near coalmines. See KHB (53.16a-b).

${ }^{36}$ The cangue was a heavy wooden plank affixed to a prisoner's neck; wearing the cangue meant being forced to wear it outside for public viewing.

${ }^{37} \mathrm{KHB}$ (44.26a-28b). In Qing Mongolia, class was a legal category and the differing standards of punishments for noblemen.

${ }^{38}$ Qingshi lu (QL1050.414.1-2).

${ }^{39}$ See Qingdai de Kuangye, 1-19.

${ }^{40}$ The literature on this pivotal period in mining history is large. See Rowe (1982), Gao Wangling, (1993: 20-22), and Wei and $\mathrm{Lu}(1981)$.

${ }^{41}$ Qingshi lu (QL921.363-1).

${ }^{42}$ Qingshi lu (QL923.383.1).

${ }^{43}$ Qingshi lu (QL939.503.1).

${ }^{44}$ Ibid.

${ }^{45}$ Liang, 304-306.

${ }^{46}$ The silver tael was a standard unit of currency in the Qing period.

${ }^{47}$ Liang, 305 and Qingshi lu (QL1039.917.1). The work environment was noted for being particularly tough on the Chinese miners, with the workforce dropping from 2000 to 800 from disease.

${ }^{48}$ Liang, 305. The prohibition did not stop migrants from crossing the border, with cases reported in 1782 and 1785. See Liang (306). 
${ }^{49}$ Kuangwu dang, 4895.

${ }^{50}$ Ibid.

${ }^{51}$ Kuangwu dang, 4896.

${ }^{52}$ Kuangwu dang, 4897.

${ }^{53}$ Frans Larson first came to Mongolia in 1893 with the Christian Missionary Alliance of New York and worked under their direction until 1900. He later came under the patronage of the monarch of Ordos and was ordained a Mongol duke by the Emperor of Mongolia. In his monograph (Larson 1930) he describes how he gained the full rights equal to those of a Mongol prince's son and provides detailed insights into the lives of noblemen until he left in 1923.

${ }^{54}$ Archival records mention that after the opening of a mine in one banner in Cecen Khan aimag, the "Mongols were all unhappy about serving" in the mines. See Kuangwu dang, 4904.

${ }^{55}$ In the late $19^{\text {th }}$ century, the Qing government came under severe financial pressure. The impact of the massive Taiping Rebellion (1850-1864) alongside that of the Muslim rebellions in the northwest of the empire (1862-1877) put a strain on the state finances and ultimately required a fundamental restructuring and refinancing of state business.

${ }_{57}^{56}$ Kuangwu dang, 4964.

${ }^{57}$ Kuangwu dang, 4906.

${ }^{58}$ Following the demonstrations there was a noticeable shift towards greater Government participation and control of mining operations. The amended Minerals Law ratified in July 2006 (State Ih Hural of Mongolia) introduced the classification of 'Strategic Mineral Deposit' (strategiin ach holbogdol bühii ashigt maltmalyn ord), where the Government has the right to acquire up to 50 percent interest in operations of substantial economic potential (Art. 5). By allowing for state equity participation, the Government can take a stake in new mines in order to maintain greater control over its mineral wealth and secure greater financial benefits. Currently, the government has identified 15 deposits as having strategic importance and has an unpublished list of another 39 that it may classify as strategic in the future (see High forthcoming). ${ }^{59}$ The histories of Chinese gold miners in the United States, Canada, and Australia are well known in the English-speaking world. Less well known, perhaps, are the histories of Chinese miners in Russia and South Africa. On Russia, see Seigelbaum (1978:313-324); on South Africa, see Richardson (1982:1-7). On gold's effect on global migration in the late $19^{\text {th }}$ century, see Sédillot (1974:217-247). 